\title{
PENGEMBANGAN SISTEM INFORMASI PADUAN SUARA MAHASISWA UNIVERSITAS DIPONEGORO BERBASIS WEB DAN SMS
}

\author{
Liga Filosa $^{1)}$, R. Rizal Isnanto ${ }^{2)}$, Adian Fatchur Rochim ${ }^{2)}$ \\ Program Studi Sistem Komputer, Fakultas Teknik, Universitas Diponegoro \\ Jln. Prof. Sudharto, Tembalang, Semarang, Indonesia \\ Email: ligafilosa@live.com
}

\begin{abstract}
Today, technology has become ours primary need. The ease of getting or giving information by using technology make people do their jobs easily. Diponegoro University Choir (PSM) is one of choir that have good reputation in local, national and international. But PSM do not have any official website that can gives information to the people. Every years, the number of recruits is increasing, and the process of registeration is still done manually. Based on that problem, the organization needs an web-based Information System and SMS gateway to support information giving process and its own member data maintenance.The Information System is built using PHP Framework Codeignitier language program, javascript for the dynamic appearance, and MySQL for the database. The System's development process uses waterfall method. This method is included with analysis of needs, analysis, design, implementation and testing. The model of system is built using object oriented UML (Unified Modeling Language) includes Use Case diagram, Class diagram and Sequence diagram.
\end{abstract}

Index Term : Web-based information system, SMS gateway, PHP, Codeigniter, MySQL, Javascript, UML.

\section{Pendahuluan}

Paduan Suara Mahasiswa Universitas Diponegoro Semarang merupakan Paduan Suara yang didirikan pada bulan oktober 1972. Merupakan paduan suara yang cangkupannya universitas, dimana anggotanya dari semua fakultas di Universitas Diponegoro. Sudah banyak sekali kompetisi baik lokal, nasional maupun internasional yang diikuti oleh PSM UNDIP. Tak hanya kompetisi, PSM UNDIP punya banyak kegiatan seperti job universitas dalam acara-acara yang dilaksanakan universitas maupun job dari berbagai ormas, partai atau organisasi lainnya.

Sampai saat ini PSM UNDIP belum mempunyai situs resmi yang merupakan kebutuhan yang sangat penting di era teknologi saat ini. Setiap tahun PSM UNDIP membuka pendaftaran untuk anggota baru, dan ini masih dilakukan dengan cara manual, mendaftar ke stand yang disediakan, lalu calon anggota baru mengisi formulir dalam bentuk kertas. Setiap tahun jumlah pendaftar semakin meningkat hal ini membuat seleksi menjadi berhari-hari. Karena sistem masih manual, banyak calon anggota baru yang harus menunggu berjamjam untuk masuk ke ruang seleksi. Karena belum adanya sistem yang mengatur jadwal seleksi yang bisa dipilih oleh calon anggota baru itu sendiri. Selain itu kordinasi antar pengurus belum bisa maksimal dalam mengelola setiap kebutuhan dari masing-masing seksi yang ada dalam mengelola surat untuk sekretaris, keuangan untuk bendahara, data kostum untuk seksi penampilan dan juga data perlengkapan untuk seksi perlengkapan PSM UNDIP.

Berdasarkan latar belakang yang sudah dijelaskan maka dapat disimpulkan bahwa PSM UNDIP membutuhkan perangkat lunak yang dapat membantu mengelola dalam menunjang kegiatan PSM UNDIP secara online. Oleh karena itu akan dilakukan penelitian dengan judul PENGEMBANGAN SISTEM INFORMASI PADUAN SUARA MAHASISWA UNIVERSITAS DIPONEGORO BERBASIS WEB DAN SMS.

\section{Tinjauan Pustaka}

\subsection{Pengertian Sistem Informasi}

Sistem informasi adalah segala sesuatu yang bekerja bersama-sama yang dibuat oleh manusia untuk mencapai suatu tujuan yaitu menyajikan informasi. Komponen sistem informasi adalah perangkat keras, perangkat lunak, manusia, data dan prosedur. Sebuah sistem informasi merupakan gabungan antara perangkat keras dan perangkat lunak yang mengolah data dan menyaikan informasi yang dibutuhkan ${ }^{[1]}$.

\subsection{Pemrograman Berorientasi Objek}

Metodologi berorientasi objek adalah suatu strategi pembangunan perangkat lunak yang mengorganisasikan perangkat lunak sebagai kumpulan objek yang berisi data dan operasi yang diberlakukan terhadapnya. Metodologi berorientasi objek merupakan suatu cara bagaimana suatu sistem perangkat lunak dibangun melalui pendekatan objek secara sistematis. Metode berorientasi objek didasarkan pada penerapan prinsip-prinsip pengelolaan kompleksitas. Metode berorientasi objek meliputi 
rangkaian aktivitas analisis berorientasi objek, perancangan berorientasi objek, pemrograman berorientasi objek, pengujian berorientasi objek[4].

\subsubsection{Pengertian Unified Modeling Language (UML)}

Unified modeling language (UML) adalah sebuah "bahasa" pemodelan untuk sistem atau perangkat lunak yang berparadigma 'berorientasi objek $^{[6]}$.

Unified modeling language (UML) adalah salah satu standar bahasa pemodelan yang banyak digunakan di dunia industri untuk mendefinisikan requrement, membuat analisi dan desain, serta menggambarkan arsitektur dalam pemrograman berorientasi objek ${ }^{[4]}$.

a. Basis Data

Basis Data adalah pengorganisasian sekumpulan data yang saling terkait sehingga memudahkan aktivitas untuk memperoleh informasi. Basis data dimaksudkan untuk mengatasi masalah pada sistem yang memakan pendekatan berbasis berkas ${ }^{[5]}$.

b. Tools Pendukung

\subsubsection{MySQL}

MySQL adalah Relational Database Management System (RDBMS) yang dapat menangani data bervolume besar. Meskipun begitu, tidak menuntut resource yang besar ${ }^{[7]}$.

\subsubsection{PHP}

PHP adalah salah satu bahasa pemrograman skrip yang dirancang untuk membangun aplikasi web. Aplikasi web adalah aplikasi yang disimpan dan dieksekusi (oleh PHP Engine) di lingkungan web server. Setiap permintaan yang dilakukan oleh user melalui aplikasi klien (web browser) akan direspon oleh aplikasi web dan hasilnya akan dikembalikan lagi ke hadapan user. Dengan aplikasi web, halaman yang tampil di layar web browser dapat bersifat dinamis, tergantung dari nilai data atau parameter yang dikirimkan oleh user ke web server ${ }^{[11]}$.

\subsubsection{CodeIgniter}

Codeigniter adalah sebuah web application framework yang bersifat open source digunakan untuk membangun aplikasi PHP dinamis. Tujuan utama pengembangan Codeigniter adalah untuk membantu pengembang untuk mengerjakan aplikasi lebih cepat daripada menulis semua code dari awal. Code igniter menyediakan berbagai macam pustaka yang dapat mempermudah dalam pengembangan. Codeigniter diperkenalkan kepada publik pada tanggal 28 februari $2008^{[12]}$.

\subsubsection{MVC pada Codeigniter \\ MVC adalah konsep dasar yang harus diketahui sebelum mengenal Codeigniter. MVC adalah}

singkatan dari Model View Controller. MVC sebenarnya adalah sebuah pattern/teknik pemrograman yang memisahkan bisnis logic (alur piker), data logic (penyimpanan data) dan presentation logic (antarmuka aplikasi) atau secara sederhana adalah memisahkan antara desain, data dan proses.

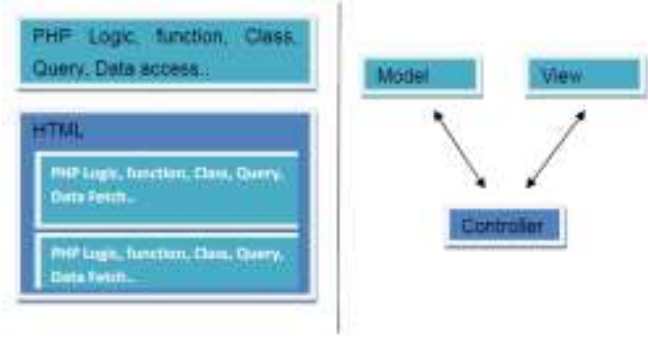

Gambar 1 Perbedaan PHP biasa dan MVC

\subsubsection{JQuery}

JQuery merupakan salah satu dari sekian banyak framework yang digunakan dan memiliki pengguna yang paling banyak. JQuery merupakan pustaka JavaScript yang dibangun untuk mempercepat dan meringkas serta menyederhanakan manipulasi dokumen HTML, penanganan event, animasi, dan interaksi Ajax untuk mempercepat pengembangan web. Dengan JQuery, developer akan dimanjakan dengan suatu pemrograman JavaScript yang sangat sederhana jika dibandingkan dengan native JavaScript ${ }^{[3]}$.

\subsubsection{Sms Gateway}

SMS gateway di artikan sebagai suatu platform yang menyediakan mekanisme untuk EUA menghantar dan menerima SMS dari peralatan mobile (HP, PDA phone, dll) melalui SMS Gateway's shortcode ${ }^{[2]}$.

SMS gateway ini memanfaatkan modem untuk server pengiriman sms. SMS memanfaatkan jaringan operator seluler untuk pengiriman sms, service gammu sebagai software sms gateway, dan basis data MySQL yang diinintegrasikan dengan basis data.

\subsubsection{Gammu}

Gammu adalah sebuah aplikasi yang dapat digunakan untuk mengelola berbagai fungsi pada telepon genggam, modem dan perangkat sejenisnya.

Fungsi-fungsi yang dapat dikelolla Gammu antara lain adalah fungsi nomor kontak dan fungsi SMS ${ }^{[10]}$.

Keunggulan Gammu dibanding tool SMS Gateway lainnya adalah :

1. Gammu bisa dijalankan di Windows maupun Linux.

2. Banyak device yang yang kompatibel dengan Gammu.

3. Gammu menggunakan basis data MySQL.

4. Kabel data USB atau serial kompatibel dengan Gammu.

5. Gammu adalah aplikasi open source yang dapat dipakai secara gratis. 
6. Gammu tidak membutuhkan banyak hardware.

7. Mudah dikembangkan dengan modal terjangkau ${ }^{[10]}$.

\section{Perancangan}

\subsection{Tahap Perancangan Sistem}

Sistem informasi yang baik tentunya membutuhkan perancangan yang matang, Layaknya membuat sebuah bangunan tentulah dibutuhkan sebuah cetak biru agar bangunan yang akan dibuat nantinya dapat tepat guna dan tepat sasaran. Oleh karena itu dalam perancangan aplikasi pada tugas akhir ini digunakan metode Waterfall. Metode ini terdiri atas beberapa tahap yaitu analisis kebutuhan, perancangan, implementasi, pengujian, pemeliharaan. Metode dapat ditunjukkan pada Gambar 2.

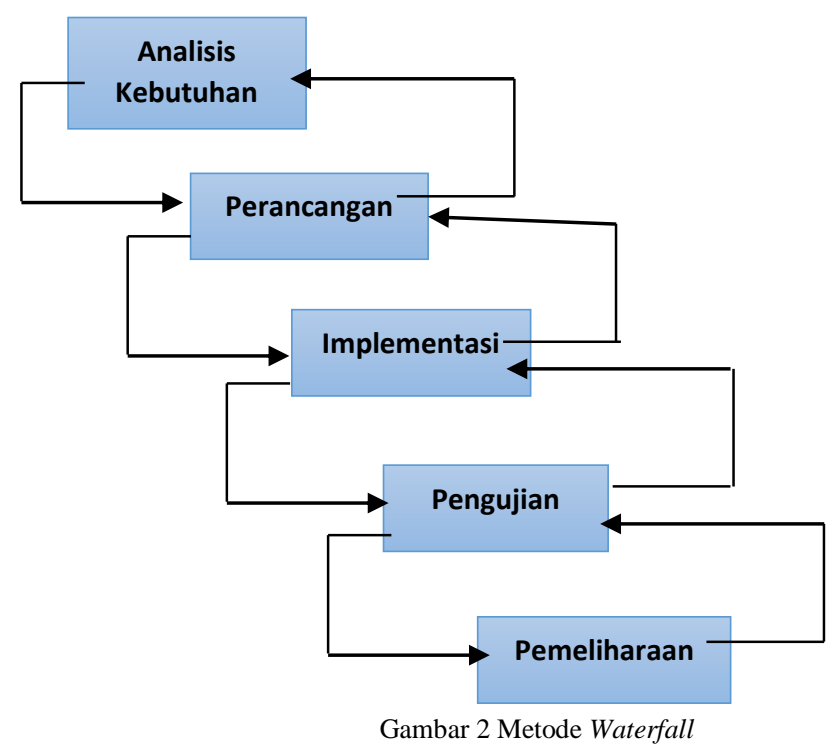

\subsection{Requirements (Analisis Kebutuhan)}

Sistem yang baik tentu sistem yang dapat memenuhi kebutuhan dari pengguna, memudahkan dan memberikan manfaat lebih dibandingkan dengan tidak menggunakan sebuah sistem. Maka dari itu untuk membangun sistem perlu dilakukan analisis kebutuhan.

\subsubsection{Deskripsi Umum}

Paduan Suara Mahasiswa Universitas Diponegoro (PSM UNDIP) merupakan salah satu UKM (Unit Kegiatan Mahasiswa) di bidang seni yang ada di Universitas Diponegoro Semarang. UKM ini melaksanakan fungsi organisasi layaknya organisasi kampus lainnya, dimana terdapat pelatih, pengurus harian dan anggota PSM UNDIP sendiri. Dalam kesehariannya, PSM UNDIP memiliki jadwal latihan, jadwal konser, jadwal kompetisi dan jadwal berbagai acara lainnya. Setiap tahun PSM UNDIP juga membuka penerimaan anggota baru yang diikuti oleh mahasiswa baru Universitas Diponegoro.

Setelah melakukan wawancara dan pengamatan secara langsung dengan pihak terkait terhadap keadaan di PSM UNDIP, diharapkan situs yang dibuat dapat:

1. Mempermudah pengurus PSM UNDIP dalam mengelola data-data yang dibutuhkan untuk kegiatan PSM UNDIP.

2. Mempermudah pengurus dalam berkordinasi dengan ketua dalam pembuatan laporan kegiatan dan data PSM UNDIP

3. Mempermudah mahasiswa baru yang ingin mendaftar menjadi anggota baru PSM UNDIP.

4. Mempermudah seksi keanggotaan dalam menginformasikan jadwal dan pengumuman penting untuk kegiatan PSM UNDIP kepada anggota atau calon anggota PSM UNDIP.

\subsubsection{Kebutuhan Pengguna}

Setelah mendeskripsikan alur pendaftaran PSM UNDIP, pihak pengguna yaitu PSM UNDIP menginginkan beberapa kondisi pada sistem informasi berdasar pada kendala yang dialami. Kebutuhan tersebut adalah manajemen data dan informasi PSM UNDIP yang mampu:

1. Mengelola isi halaman situs PSM UNDIP

2. Mengelola data dari setiap seksi dalam PSM UNDIP

3. Mengelola pendaftaran anggota baru PSM UNDIP

4. Memberikan informasi kepada anggota dan calon anggota melalui SMS Gateway

\subsubsection{Aktor yang terlibat}

Berdasarkan tahapan dari deskripsi umum sebelumnya, dalam pembuatan sistem informasi ini ada beberapa tingkatan aktor, yang dapat dibagi menjadi empat tingkatan penguna, yaitu :

1. Admin adalah tingkatan pengelola dari sistem tertinggi yang di sini.

2. Pengurus PSM UNDIP yang masing-masing memiliki username dan password untuk masuk dalam sistem dan hanya mengelola data sesuai fungsinya dalam organisasi PSM UNDIP.

3. Mahasiswa baru adalah tingkatan pengguna dari sistem yang bertindak sebagai objek sasaran pendaftaran anggota baru.

4. Umum adalah tingkatan pengguna dari sistem yang bertindak sebagai objek pengguna umum dan tidak memiliki hak akses apapun di dalam sistem. 
Pengguna ini hanya bisa melihat informasi profil, anggota dan jadwal saja.

\subsubsection{Kebutuhan Aplikasi}

Kebutuhan ini merupakan kebutuhan yang mendukung implementasi sistem yang akan dibuat. Dalam penerapannya, dibagi menjadi dua kategori yaitu : 1. Operasional

Kebutuhan minimum yang diperlukan untuk menjalankan aplikasi ini adalah sebagai berikut :

\section{a. Sistem Operasi}

Sistem operasi yang dapat digunakan untuk menjalankan aplikasi berbasis framework Code Igniter 2.1.4 antara lain Windows, Mac OS, dan Linux asalkan dilengkapi dengan aplikasi web server.

\section{b. PHP (PHP Hypertext Preprocessor)}

Code igniter 2.1.4 dijalankan dengan bahasa pemrograman PHP dengan spesifikasi versi PHP minimum yaitu versi 5.1.6.

c. Web Browser

Aplikasi ini dirancang dalam basis aplikasi web oleh karena itu, di sisi klien aplikasi web browser sangat diperlukan. Hampir semua web browser dapat digunakan untuk mengakses aplikasi ini seperti Internet Explorer 7 ke atas, Mozilla Firefox, Google Chromer, Safari, dan lainnya.

\section{d. Basis Data}

Basis data yang digunakan sebagai media penyimpanan data dapat menggunakan MySQL 4.1+, MySQLi, MS SQL, Postgres, Oracle, SQLite dan ODBC. Basis data tersebut yang mendukung Code Igniter 2.1.4.

\section{Interface/Antarmuka}

Antarmuka pengguna atau user interface adalah penghubung antara aplikasi sistem informasi dengan pengguna. Kebutuhan terhadap antar muka yang diinginkan sebaik mungkin dapat menggunakan perangkat lunak yang dibuat dengan mudah dan senyaman mungkin untuk mendapatkan informasi yang diinginkan.

\section{Keamanan}

Keamanan data merupakan salah satu unsur yang penting dalam pembuatan sebuah sistem. Karena suatu sistem tanpa keamanan data yang baik akan merugikan sistem itu sendiri, sebab data akan bebas diakses oleh pihak-pihak yang tidak bertanggung jawab. Keamanan data dapat dilakuakn dengan penggunaan password dalam form login untuk membedakan pengguna termasuk hak akses masing-masing dengan enkripsi MD5.

\subsection{Perancangan}

Tahap ketiga yaitu tahap perancangan/desain perangkat lunak yang merupakan proses multi langkah dan berfokus pada beberapa atribut perangkat lunak.

\subsubsection{Entity Relationship Diagram (ERD)}

Entity Relationship Diagram (ERD) adalah salah satu metode pemodelan perangkat lunak yang biasanya digunakan dalam tahap analisis perancangan basis data. ERD berupa model data konseptual yang merepresentasikan data tertentu.

1. Menentukan entitas tahapan ERD dimulai dengan mengidentifikasi dan menetapkan seluruh himpunan entitas yang terlibat.. ERD ditunjukkan pada Gambar 4.

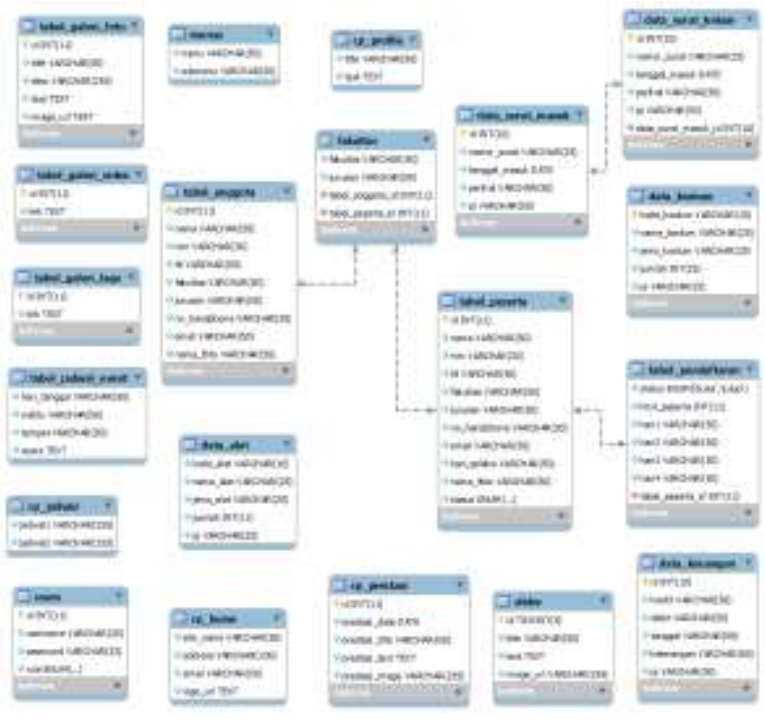

Gambar 4 Entitas Relationship Diagram 


\subsubsection{UML (Unified Modeling Language)}

\section{Definisi Aktor}

Berikut ini adalah deskripsi pendefinisian aktor pada aplikasi Sistem Informasi Paduan Suara Mahasiswa Universitas Diponegoro yang ditunjukkan pada Tabel 1.

Tabel 1 Deskripsi Pendefinisian Aktor

\begin{tabular}{|l|l|l|}
\hline No & Aktor & Deskripsi \\
\hline 1 & Admin & $\begin{array}{l}\text { Admin memiliki hak akses tertinggi untuk } \\
\text { mengelola data PSM UNDIP. }\end{array}$ \\
\hline 2 & Pengurus & $\begin{array}{l}\text { Memiliki hak akses sesuai fungsinya dalam } \\
\text { organisasi PSM UNDIP. }\end{array}$ \\
\hline 3 & $\begin{array}{l}\text { Calon } \\
\text { Anggota }\end{array}$ & $\begin{array}{l}\text { Mahasiswa baru yang ingin mendaftar } \\
\text { menjadi anggota PSM UNDIP. Dapat } \\
\text { mengisi formulir pendaftaran saat waktu } \\
\text { pendaftaran di buka. }\end{array}$ \\
\hline 4 & Umum & $\begin{array}{l}\text { Orang yang memiliki hak akses sebatas } \\
\text { hanya melihat informasi profil, anggota dan } \\
\text { jadwal PSM UNDIP tanpa bisa } \\
\text { memberikan komentar apapun. }\end{array}$ \\
\hline
\end{tabular}

Deskripsi atau penjelasan dari masing-masing use case pada gambar 3.4 dapat dilihat pada Tabel 3.21.

Tabel 2 Deskripsi Pendefinisian Use Case

\begin{tabular}{|c|c|c|}
\hline No & Use Case & Deskripsi \\
\hline 1 & $\begin{array}{ll}\text { Melihat } & \text { Situs } \\
\text { Profil } & \text { PSM } \\
\text { UNDIP } & \end{array}$ & $\begin{array}{l}\text { Melihat profil PSM UNDIP dalam } \\
\text { halaman web. }\end{array}$ \\
\hline 2 & $\begin{array}{l}\text { Melakukan } \\
\text { Pendaftaran }\end{array}$ & $\begin{array}{l}\text { Calon anggota baru yang akan } \\
\text { mendaftaran ketika pendaftaran di } \\
\text { buka mengisi formulir yang sudah } \\
\text { disediakan di dalam web. }\end{array}$ \\
\hline 3 & $\begin{array}{l}\text { Mengelola } \\
\text { Halaman Situs }\end{array}$ & $\begin{array}{l}\text { Seksi humas mengelola isi dari situs } \\
\text { yang akan ditampilkan. }\end{array}$ \\
\hline 4 & $\begin{array}{ll}\text { Mengelola } \\
\text { anggota }\end{array}$ & $\begin{array}{l}\text { Seksi keanggotaan mengelola data } \\
\text { anggota PSM UNDIP. }\end{array}$ \\
\hline 5 & $\begin{array}{l}\text { Mengelola Data } \\
\text { Peserta }\end{array}$ & $\begin{array}{l}\text { Seksi keanggotaan mengelola data } \\
\text { calon anggota baru PSM UNDIP. }\end{array}$ \\
\hline 6 & Mengelola SMS & $\begin{array}{l}\text { Seksi keanggotaan mengelola sms } \\
\text { untuk memberikan informasi kepada } \\
\text { anggota dan calon anggota PSM } \\
\text { UNDIP. }\end{array}$ \\
\hline 7 & $\begin{array}{l}\text { Mengelola Data } \\
\text { Surat }\end{array}$ & $\begin{array}{l}\text { Sekretaris mengelola data surat masuk } \\
\text { dan keluar untuk dokumentasi laporan } \\
\text { pertanggungjawaban. }\end{array}$ \\
\hline 8 & $\begin{array}{l}\text { Mengelola Data } \\
\text { Keuangan }\end{array}$ & $\begin{array}{l}\text { Bendahara mengelola aliran dana yang } \\
\text { masuk dan keluar yang digunakan } \\
\text { untuk kegiatan operasional PSM } \\
\text { UNDIP. }\end{array}$ \\
\hline
\end{tabular}

\begin{tabular}{|l|l|l|}
\hline 9 & $\begin{array}{l}\text { Mengelola Data } \\
\text { Penampilan }\end{array}$ & $\begin{array}{l}\text { Seksi penampilan mengelola data } \\
\text { kostum dan lain-lain yang berkaitan } \\
\text { dengan penampilan PSM UNDIP. }\end{array}$ \\
\hline 10 & $\begin{array}{l}\text { Mengelola Data } \\
\text { Perlengkapan }\end{array}$ & $\begin{array}{l}\text { Seksi Perlengkapan mengelola data } \\
\text { perlengkapan alat-alat PSM UNDIP } \\
\text { yang digunakan dalam berbagai } \\
\text { kegiatan PSM UNDIP. }\end{array}$ \\
\hline 11 & Melihat Laporan & $\begin{array}{l}\text { Ketua dan admin dapat melihat laporan } \\
\text { dari masing-masing seksi. }\end{array}$ \\
\hline 12 & $\begin{array}{l}\text { Mengelola } \\
\text { Pengguna }\end{array}$ & $\begin{array}{l}\text { Admin memiliki hak akses untuk } \\
\text { mengatur pengguna yang bisa masuk } \\
\text { ke dalam sistem. }\end{array}$ \\
\hline
\end{tabular}

Gambar 5 dan Gambar 6 menggambarkan Diagram Use Case Sistem Informasi Paduan Suara Mahasiswa Universitas Diponegoro.

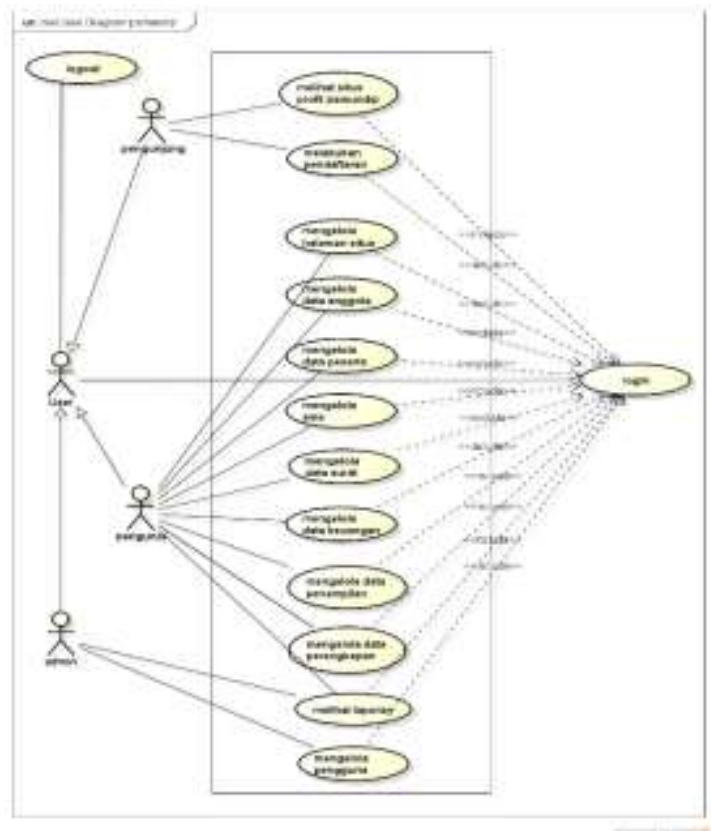

Gambar 5 Use Case Diagram Sistem Informasi PSM UNDIP

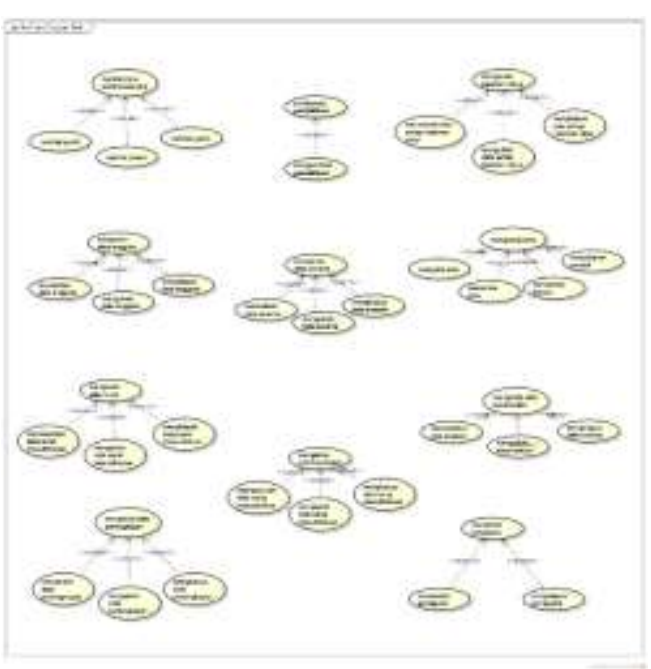

Gambar 6 Use Case Diagram Detil Sistem Informasi PSM UNDIP 


\section{Diagram Kelas}

Diagram kelas menggambarkan struktur dan deskripsi class, package, dan objek beserta hubungan satu sama lain seperti containment, pewarisan, asosiasi, dan lain-ain. Diagram kelas berfungsi untuk menjelaskan tipe dari objek sistem dan hubungannya dengan objek yang lain. Objek adalah nilai tertentu dari setiap entitas attribut kelas. Berikut kelas diagram dari sistem yang akan dibangun ditunjukkan pada Gambar 7:

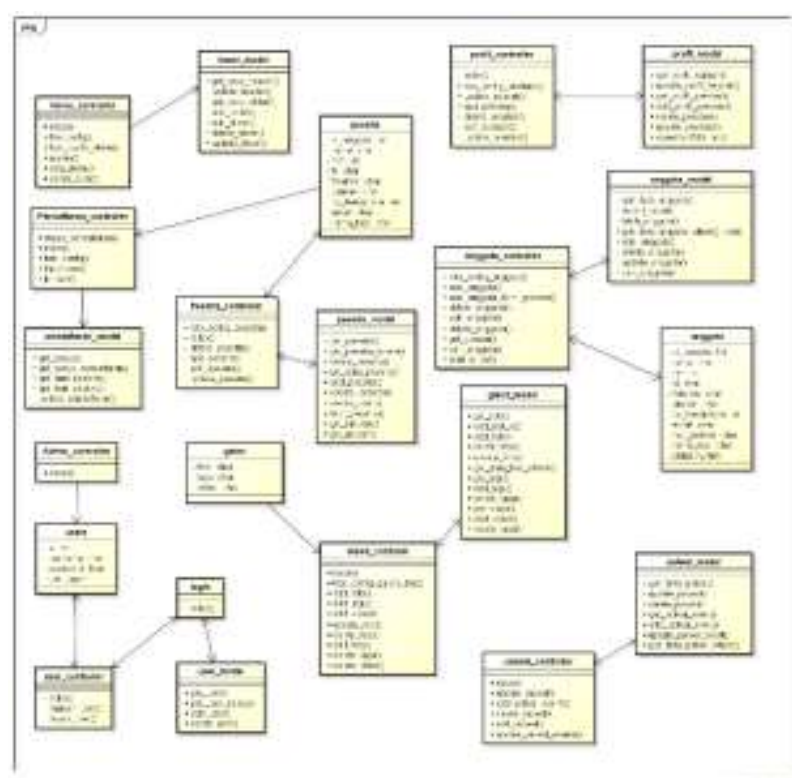

Gambar 7 Diagram kelas

\section{Diagram Sekuens}

Diagram Sekuens digunakan untuk menggambarkan interaksi antarobjek didalam dan disekitar sistem yang berupa pesan yang digambarkan terhadap waktu. Diagram sekuens terdiri antara dimensi vertikal (waktu) dan dimensi horizontal (objek-objek yang terkait).

\section{Diagram sekuens login}

Diagram sekuens login yang berisi interaksi aktor dengan sistem pada saat proses login, berikut adalah diagram sekuens login yang ditunjukkan oleh Gambar 8.

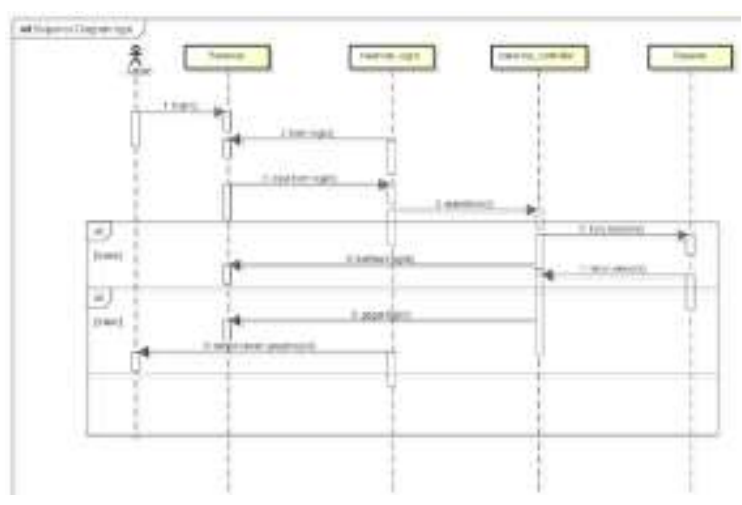

Gambar 8 Diagram sekuens Login

2. Diagram sekuens mengelola halaman beranda
Diagram sekuens mengelola beranda yang berisi interaksi aktor dengan sistem pada saat proses menglola tampilan beranda. Berikut adalah diagram sekuens mengelola halaman beranda yang ditunjukkan oleh Gambar 9 .

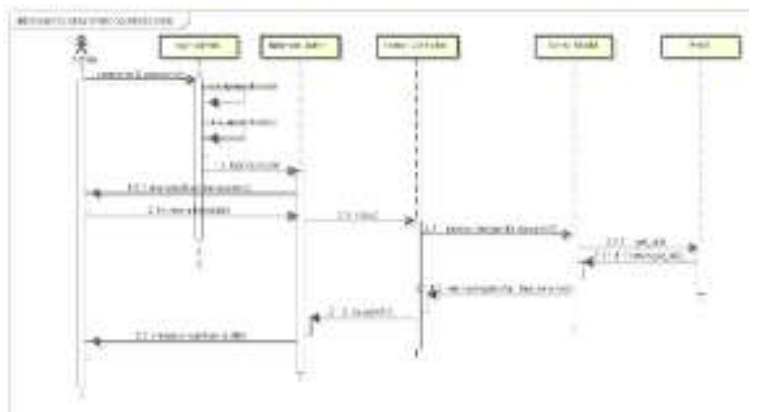

Gambar 9 Diagram Sekuens Mengelola Halaman Beranda

3. Diagram sekuens mengelola halaman profil

Diagram sekuens mengelola halaman profil yang berisi interaksi aktor dengan sistem pada saat proses mengelola profil. Berikut adalah diagram sekuens mengelola halaman profil yang ditunjukkan oleh Gambar 10 .

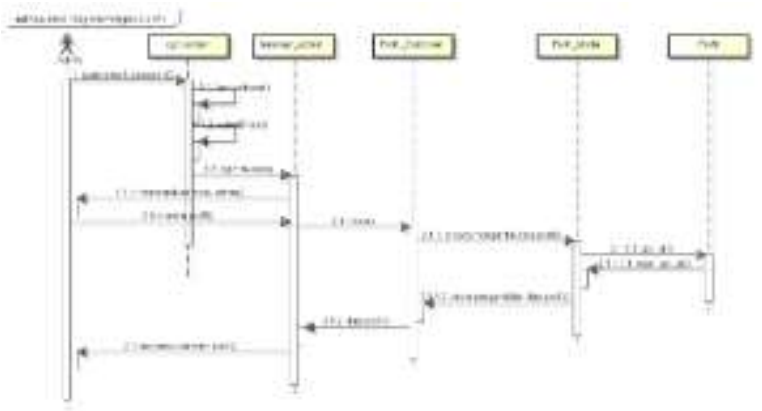

Gambar 10 Diagram Sekuens Mengelola Halaman Profil

4. Diagram sekuens mengelola menu pendaftaran

Diagram sekuens mengelola menu pendaftaran berisi interaksi aktor dengan sistem pada saat proses mengelola menu pendaftaran. Berikut adalah diagram sekuens mengelola menu pendaftaran yang ditunjukkan oleh Gambar 11.

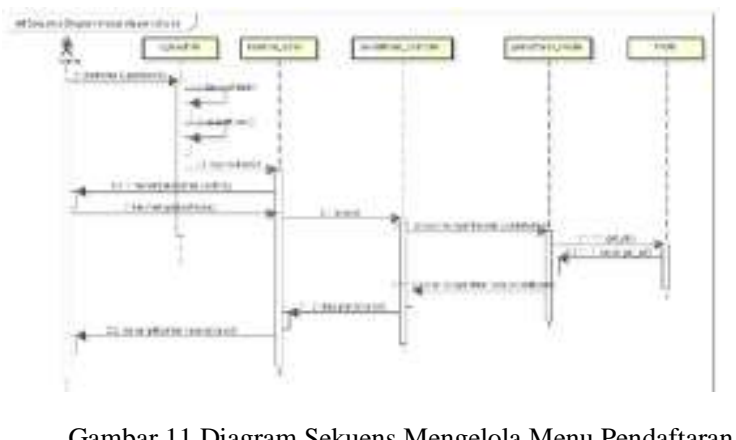

5. Diagram sekuens melihat halaman profil

Diagram sekuens melihat halaman profil, berisi interaksi aktor dengan sistem pada saat proses melihat halam profil. 
Berikut ini diagram sekuens melihat halaman profil yang ditunjukkan oleh Gambar 3.12.

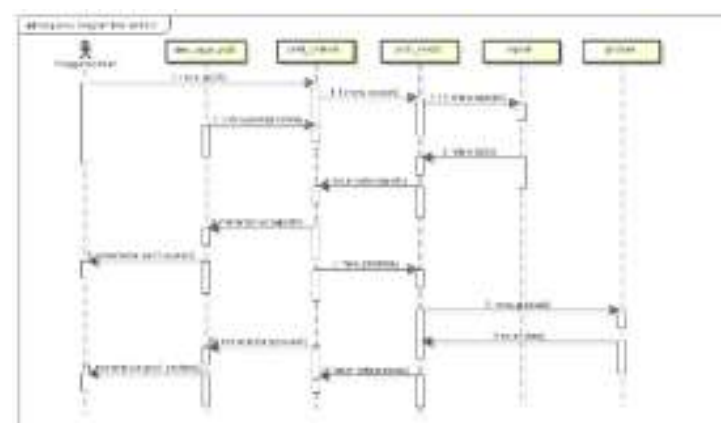

Gambar 12 Diagram Sekuens Melihat Halaman Profil

6. Diagram sekuens melakukan pendaftaran

Diagram sekuens melakukan pendaftaran, berisi interaksi aktor dengan sistem pada saat proses melakukan pendaftaran. Berikut ini diagram sekuens melakukan pendaftaran yang ditunjukkan oleh Gambar 12 .

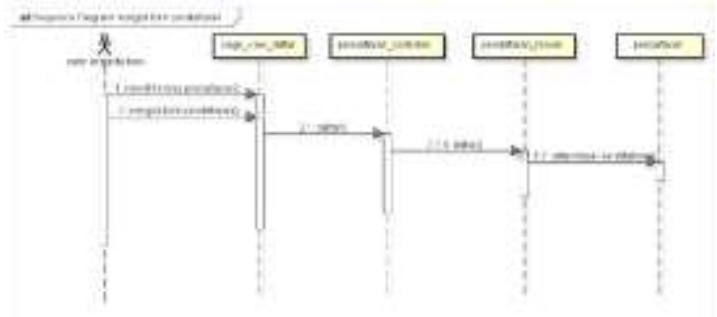

Gambar 12 Diagram Sekuens Melakukan Pendaftaran

7. Diagram sekuens mengirim SMS pemesanan layanan

Diagram sekuens mengirim SMS pemesanan layanan berisi interaksi aktor dengan sistem pada saat proses mengirim SMS, yang terdiri dari controller: control_SMS_gateway, dan entitas: inbox_SMS_gateway, user_data. Berikut adalah diagram sekuens mengirim SMS yang ditunjukkan oleh Gambar 13:

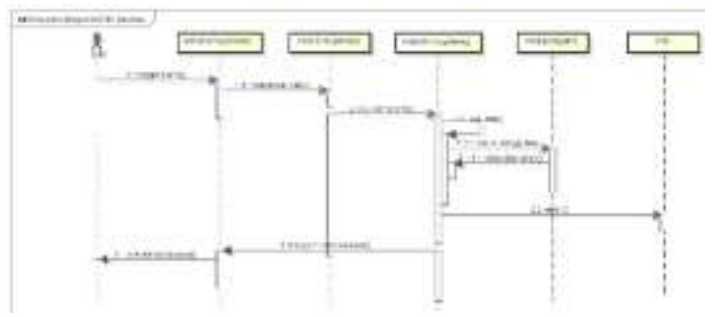

Gambar 13 Diagram Sekuens Mengirim SMS

\section{Deployment Diagram}

Deployment/physical diagram menggambarkan detail bagaimana komponen di-deploy dalam infrastruktur sistem, di mana komponen akan terletak (pada mesin, server atau piranti keras apa). Deployment diagram sistem yang akan dibangun ditunjukan pada Gambar 14.

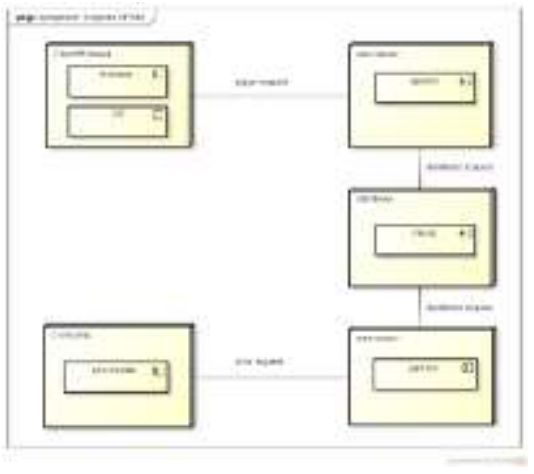

Gambar 14 Deployment Diagram Sistem Informasi PSM UNDIP

\subsubsection{Perancangan Antarmuka}

1. Tampilan utama halaman publik

Desain tampilan awal halaman publik menampilan sekilas profil PSM UNDIP yang disajikan dalam bentuk foto slider dan teks slider yang berisi profil singkat dan smbutan dari ketua dan pelatih PSM UNDIP. Berikut adalah desain halaman utama website PSM UNDIP, ditunjukkan pada Gambar 15.

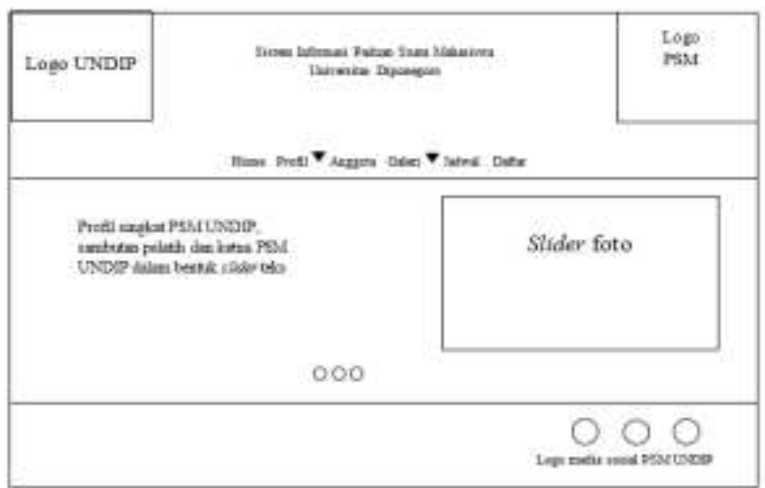

Gambar 15 Tampilan Awal Halaman Publik (Beranda)

2. Tampilan halaman anggota

Tampilan halaman anggota dapat ditunjukkan pada Gambar 16.

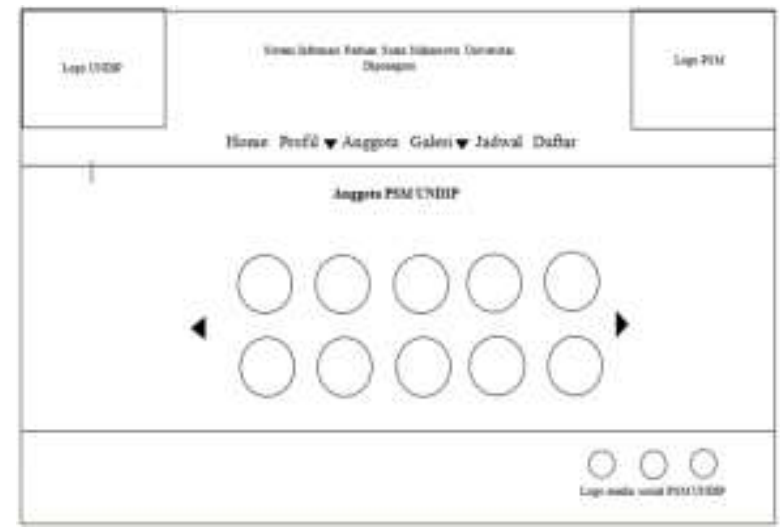

Gambar 16 Tampilan Halaman Anggota 


\section{Tampilan halaman galeri}

Tampilan halaman galeri terbagi kedalam 3 menu yaitu foto, lagu dan video. Berikut adalah desain halaman galeri, ditunjukkan pada Gambar 17, Gambar 18 dan Gambar 19.

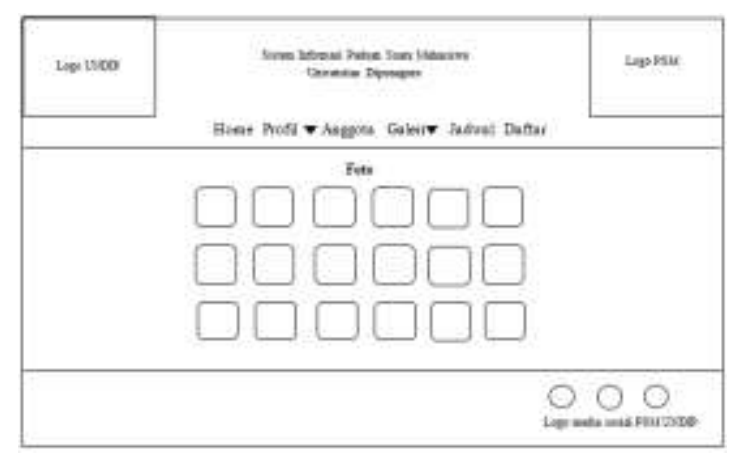

Gambar 17 Tampilan Galeri : foto

\section{IMPLEMENTASI DAN PENGUJIAN SISTEM}

\subsection{Implementasi}

\subsubsection{Implementasi tabel}

Pembuatan Basis Data dilakukan menggunakan bahasa SQL (Structure Query Language), dimana Basis Data ini atau DBMS (Database Management System) yang digunakan adalah MySQL. Adapun implementasi yang di bahas yaitu, tampilan Basis Data pada aplikasi server lokal Apache Xampp for Windows v.1.8.1 sebelum mengimplementasikan rancangan tabel-tabel, terlebih dahulu membuat basis data terlebih dahulu untuk menampung semua tabel. Gambar 18 menunjukkan pembuatan basia data di MySQL.

\section{Databases}

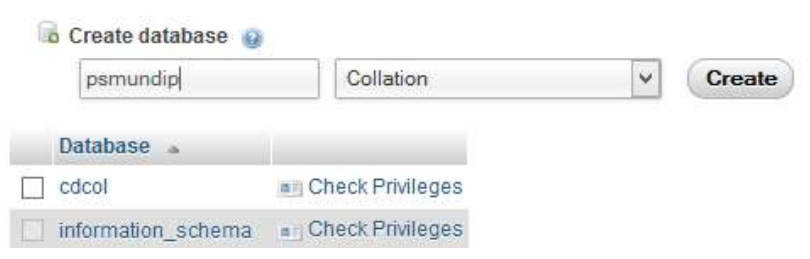

Gambar 18 Pembuatan Basis Data

\subsubsection{Implementasi Program}

Setelah basis data selesai dibentuk dengan tabeltabel di dalamnya, selanjutnya yaitu implementasi program. Implementasi program dibagi menjadi dua tahap yaitu membuat antarmuka pengguna dan sistem kerja aplikasi. Karena code igniter menggunakan prinsip MVC, maka sistem kerja aplikasi dikelola oleh model dan controller sedangkan user interface dikelola oleh view.

\section{Membuat Halaman Publik}

Tampilan halaman awal website PSM UNDIP berisi enam menu yaitu beranda, profil, anggota, jadwal, dan pendaftaran. Di bagian tengah berisi slider foto dan paragraf mengenai profil singkat PSM UNDIP. Tampilan awal situs ditunjukkan pada Gambar 19.

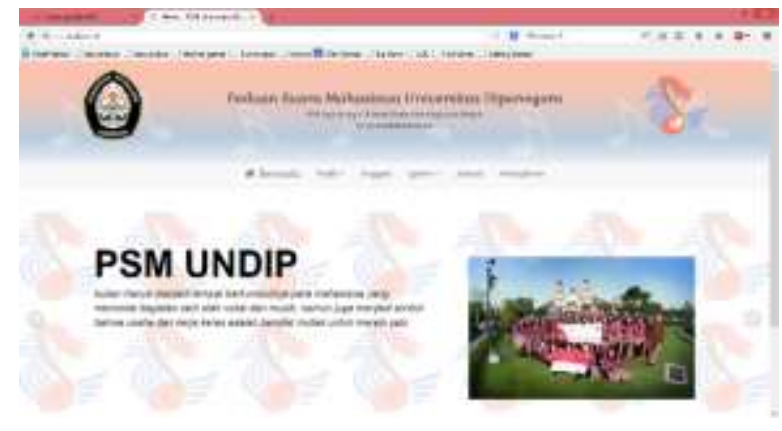

Gambar 19 Tampilan Halaman Awal Website PSM UNDIP

\subsubsection{Pengujian Sistem}

Proses pengujian menggunakan metode black-box dibagi menurut fungsi dari masing-masing menu sesuai dengan kegunaannya. Bentuk pengujian berupa cara pengguna menggunakan aplikasi.

Pengujian pertama dilakukan untuk halaman admin atau pengurus. Pengujian menu login untuk admin dan pengurus ditunjukkan pada tabel 3.

Tabel 3 Pengujian Menu login

\begin{tabular}{|c|c|c|c|}
\hline Nama Pengujian & $\begin{array}{c}\text { Bentuk } \\
\text { Pengujian }\end{array}$ & $\begin{array}{c}\text { Hasil yang } \\
\text { Diharapkan }\end{array}$ & $\begin{array}{c}\text { Hasil } \\
\text { Pengujian }\end{array}$ \\
\hline $\begin{array}{c}\text { Pengujian } \\
\text { tampilan awal } \\
\text { menu login }\end{array}$ & $\begin{array}{c}\text { Mengetikkan } \\
\text { http://www.psm }\end{array}$ & $\begin{array}{c}\text { Menampilkan } \\
\text { pop lalu masuk } \\
\text { ke halaman } \\
\text { login }\end{array}$ & Berhasil \\
\hline $\begin{array}{c}\text { Pengujian } \\
\text { fungsi login }\end{array}$ & $\begin{array}{c}\text { Memasukkan } \\
\text { username }\end{array}$ & $\begin{array}{c}\text { Muncul } \\
\text { halaman }\end{array}$ & Berhasil \\
& password & utama & aplikasi \\
\hline
\end{tabular}

Pengujian selanjutnya dengan pengujian pada menu-menu yang digunakan pengguna pada tingkatan admin dan pengurus. Pengujian tersebut ditunjukan pada Tabel 4.

Tabel 4 Tabel Pengujian Menu Mengelola Beranda (seksi humas)

\begin{tabular}{|l|l|l|l|}
\hline $\begin{array}{l}\text { Nama } \\
\text { Pengujian }\end{array}$ & Bentuk Pengujian & $\begin{array}{l}\text { Hasil Yang } \\
\text { Diharapkan }\end{array}$ & $\begin{array}{l}\text { Hasil } \\
\text { Pengujian }\end{array}$ \\
\hline $\begin{array}{l}\text { Pengujian } \\
\text { tampilan } \\
\text { awal menu } \\
\text { beranda }\end{array}$ & $\begin{array}{l}\text { Memilih menu } \\
\text { beranda pada } \\
\text { sidebar }\end{array}$ & $\begin{array}{l}\text { Menampilkan } \\
\text { form untuk } \\
\text { mengelola isi }\end{array}$ & Berhasil \\
\hline
\end{tabular}




\begin{tabular}{|c|c|c|c|}
\hline & & $\begin{array}{l}\text { tampilan } \\
\text { beranda }\end{array}$ & \\
\hline $\begin{array}{l}\text { Pengujian } \\
\text { mengubah } \\
\text { isi header } \\
\text { situs }\end{array}$ & $\begin{array}{l}\text { Mengisi form } \\
\text { ubah isi header, } \\
\text { lalu Menekan } \\
\text { tombol simpan }\end{array}$ & $\begin{array}{l}\text { Header } \\
\text { berubah }\end{array}$ & Berhasil \\
\hline $\begin{array}{l}\text { Pengujian } \\
\text { menambah } \\
\text { slider }\end{array}$ & $\begin{array}{lr}\text { Mengisi form } \\
\text { tambah slider, lalu } \\
\text { Menekan tombol } \\
\text { simpan }\end{array}$ & $\begin{array}{l}\text { Menampilkan } \\
\text { pemberitahuan } \\
\text { slider berhasil } \\
\text { ditambah dan } \\
\text { slider baru } \\
\text { masuk dalam } \\
\text { tabel slider }\end{array}$ & Berhasil \\
\hline $\begin{array}{l}\text { Pengujian } \\
\text { mengubah } \\
\text { isi slider }\end{array}$ & $\begin{array}{lr}\text { Menekan } & \text { ikon } \\
\text { ubah pada } & \text { slider } \\
\text { yang ingin diubah, } & \text { mengubah } \\
\text { dalam } & \text { form, } \\
\text { Menekan tombol } \\
\text { simpan }\end{array}$ & $\begin{array}{l}\text { Menampilkan } \\
\text { pemberitahuan } \\
\text { data berhasil } \\
\text { di ubah dan } \\
\text { data dalam } \\
\text { tabel sider } \\
\text { berubah }\end{array}$ & Berhasil \\
\hline
\end{tabular}

Pengujian pada menu profil ditunjukkan pada Tabel 4.

Tabel 4 Pengujian Menu Profil (seksi humas)

\begin{tabular}{|c|c|c|c|}
\hline $\begin{array}{l}\text { Nama } \\
\text { Pengujian }\end{array}$ & $\begin{array}{l}\text { Bentuk } \\
\text { Pengujian }\end{array}$ & $\begin{array}{l}\text { Hasil Yang } \\
\text { Diharapkan }\end{array}$ & $\begin{array}{l}\text { Hasil } \\
\text { Pengujian }\end{array}$ \\
\hline $\begin{array}{l}\text { Pengujian } \\
\text { menu } \\
\text { profil }\end{array}$ & $\begin{array}{l}\text { Memilih menu } \\
\text { profil } \\
\text { sidebar }\end{array}$ & $\begin{array}{l}\text { Menampilkan } \\
\text { form profil } \\
\text { dengan dua tab } \\
\text { yaitu sejarah } \\
\text { dan prestasi }\end{array}$ & Berhasil \\
\hline $\begin{array}{l}\text { Pengujian } \\
\text { mengubah } \\
\text { isi sejarah }\end{array}$ & $\begin{array}{l}\text { Menekan tab } \\
\text { sejarah, } \\
\text { menubah isi, } \\
\text { Menekan } \\
\text { tombol simpan }\end{array}$ & $\begin{array}{l}\text { Menampilkan } \\
\text { pemberitahuan } \\
\text { data berhasil di } \\
\text { simpan dan data } \\
\text { sejarah berhasil } \\
\text { di ubah }\end{array}$ & Berhasil \\
\hline $\begin{array}{l}\text { Pengujian } \\
\text { menamba } \\
\text { hkan data } \\
\text { prestasi }\end{array}$ & $\begin{array}{l}\text { Menekan tab } \\
\text { prestasi, } \\
\text { mengisi form } \\
\text { tambah prestasi, } \\
\text { Menekan } \\
\text { tombol tambah }\end{array}$ & $\begin{array}{l}\text { Menampilkan } \\
\text { pemberitahuan } \\
\text { data berhasil } \\
\text { ditambah dan } \\
\text { data } \\
\text { ditampilkan } \\
\text { dalam tabel } \\
\text { prestasi }\end{array}$ & Berhasil \\
\hline $\begin{array}{l}\text { Pengujian } \\
\text { tombol } \\
\text { hapus } \\
\text { prestasi }\end{array}$ & $\begin{array}{l}\text { Menekan ikon } \\
\text { tombol hapus } \\
\text { pada tabel } \\
\text { prestasi yang } \\
\text { ingin dihapus }\end{array}$ & $\begin{array}{l}\text { Menampilkan } \\
\text { data yang } \\
\text { berhasil dihapus }\end{array}$ & Berhasil \\
\hline
\end{tabular}

Tabel 5 Pengujian Halaman Anggota (seksi kenggotaan)

\begin{tabular}{|l|l|l|l|}
\hline $\begin{array}{l}\text { Nama } \\
\text { Pengujian }\end{array}$ & $\begin{array}{l}\text { Bentuk } \\
\text { Pengujian }\end{array}$ & $\begin{array}{l}\text { Hasil Yang } \\
\text { Diharapkan }\end{array}$ & $\begin{array}{l}\text { Hasil } \\
\text { Pengujian }\end{array}$ \\
\hline $\begin{array}{l}\text { Pengujian } \\
\text { menu } \\
\text { anggota }\end{array}$ & $\begin{array}{l}\text { Memilih menu } \\
\text { anggota pada } \\
\text { sidebar }\end{array}$ & $\begin{array}{l}\text { Menampilkan } \\
\text { tabel anggota, } \\
\text { form menambah } \\
\text { anggota, fungsi } \\
\text { cari dan tombol } \\
\text { untuk unduh pdf }\end{array}$ & Berhasil \\
\hline
\end{tabular}

\begin{tabular}{|l|l|l|l|}
\hline $\begin{array}{l}\text { Pengujian } \\
\text { cari } \\
\text { anggota }\end{array}$ & $\begin{array}{l}\text { Mengetikkan } \\
\text { parameter yang } \\
\text { ingin dicari }\end{array}$ & $\begin{array}{l}\text { Menunjukkan } \\
\text { yang di cari }\end{array}$ & Berhasil \\
\hline $\begin{array}{l}\text { Pengujian } \\
\text { ubah data } \\
\text { anggota }\end{array}$ & $\begin{array}{l}\text { Menekan ikon } \\
\text { ubah pada tabel } \\
\text { anggota yang } \\
\text { ingin diubah }\end{array}$ & $\begin{array}{l}\text { Menampilkan } \\
\text { data anggota } \\
\text { dalam form } \\
\text { ubah anggota }\end{array}$ & Berhasil \\
\hline $\begin{array}{l}\text { Pengujian } \\
\text { Menghap data } \\
\text { anggota }\end{array}$ & $\begin{array}{l}\text { Menekan ikon } \\
\text { tombol hapus } \\
\text { pada tabel } \\
\text { anggota yang } \\
\text { ingin dihapus }\end{array}$ & $\begin{array}{l}\text { Menampilkan } \\
\text { pemberitahuan } \\
\text { data berhasil di } \\
\text { hapus dan data } \\
\text { berhasil dihapus } \\
\text { dari tabel. }\end{array}$ & Berhasil \\
\hline $\begin{array}{l}\text { Pengujian } \\
\text { tombol } \\
\text { unduh } \\
\text { PDF }\end{array}$ & $\begin{array}{l}\text { Menekan } \\
\text { tombol unduh } \\
\text { PDF }\end{array}$ & $\begin{array}{l}\text { Menampilkan } \\
\text { data anggota } \\
\text { dalam bentuk } \\
\text { PDF }\end{array}$ & Berhasil \\
\hline
\end{tabular}

\section{KESIMPULAN DAN SARAN}

\subsection{Kesimpulan}

Dari hasil pengujian dan analisis Sistem Informasi Paduan Suara Mahasiswa Univeristas Diponegoro Berbasis Web dan SMS dapat disimpulkan beberapa hal berikut.

1. Sistem Informasi Paduan Suara Mahasiswa Universitas Diponegoro sudah dapat menampilkan informasi lengkap tentang PSM UNDIP.

2. Sistem Informasi Paduan Suara Mahasiswa Universitas Diponegoro sudah dapat mengelola data masing-masing seksi PSM UNDIP.

3. SMS gateway sudah bisa digunakan untuk mengirimkan pesan kepada anggota PSM UNDIP maupun peserta calon anggota PSM UNDIP.

4. Meskipun sistem berjalan secara baik, namun masih terdapat kendala ketika user menginputkan nomer yang salah, belum ada sistem verifikasi data melalui SMS.

5. Pada aplikasi sms gateway masih terdapat kendala seperti gangguan provider dan pengaturan servis sms gateway pada windows sehingga menyebabkan data tidak masuk pada server sms gateway.

\subsection{Saran}

Saran untuk pengembangan perangkat lunak di masa yang akan datang, antara lain:

1. Perlu dilakukan penelitian lebih lanjut untuk mengembangkan Sistem Informasi Paduan Suara Mahasiswa Universitas Diponegoro agar tidak sekedar informasi profil Paduan Suara Mahasiswa Universitas Diponegoro tetapi juga menampilkan halaman berita yang terkait dengan PSM UNDIP, anggota yang bisa membuat akun dan chatroom. 
2. Perlu dilakukan penelitian lebih lanjut untuk mengembangkan Sistem Informasi Paduan Suara Mahasiswa Universitas Diponegoro yang memiliki kemampuan integrasi dengan sistem informasi paduan suara fakultas-fakultas yang ada di UNDIP.

3. Perlu dilakukan penelitian lebih lanjut untuk mengembangkan Sistem Informasi Paduan Suara Mahasiswa Universitas Diponegoro yang memiliki kemampuan untuk dapat diakses lewat perangkat telekomunikasi mobile.

4. Perlu dilakukan penelitian lebih lanjut untuk mengembangkan Sistem Informasi Paduan Suara Mahasiswa Universitas Diponegoro yang memiliki kemampuan untuk memberikan notifikasi lewat perangkat telekomunikasi mobile.

5. Perlu dilakukan penelitian lebih lanjut untuk mengembangkan Sistem Informasi Paduan Suara Mahasiswa Universitas Diponegoro dengan tambahan fitur sistem pendukung keputusan penerimaan anggota baru PSM UNDIP.

6. Aplikasi sms gateway masih dapat dikembangkan lagi misalnya fitur untuk menghindari kesalahan input data nomer handphone yang menggunakan verifikasi kode melalui sms.

7. Melakukan backup data secara berkala untuk menanggulangi jika terjadi kehilangan maupun kerusakan data dapat dikembangkan menjadi sebuah fitur baru yang mendukung keterjaminan data pada sistem informasi.

\section{Daftar Pustaka}

[1] Kristanto, Andri, Perancangan Sistem Informasi dan Aplikasinya, Gaya Media, Yogyakarta, 2008.

[2] Ladjamudin, Al Bahra Bin, Analisis dan Desain Sistem Informasi, Penerbit Graha Ilmu, Yogyakarta, 2007.

[3] Westriningsih, Belajar JavaScript menggunakan JQuery. ANDI. Yogyakarta. 2012

[4] A.S, Rossa dkk, Rekayasa Perangkat Lunak Terstruktur dan Berorientasi Objek, Informatika Bandung, Bandung, 2013

[5] Kadir, Abdul. Pengenalan Sistem Informasi, Penerbit Andi, Yogyakarta, 2003.

[6] Nugroho, Adi. Rekayasa Perangkat Lunak Berorientasi Objek dengan Metode USDP, Penerbit Andi, Yogyakarta, 2010.

[7] Komputer, Wahana. Panduan Belajar MySQL Database Server, Mediakita, Jakarta, 2010.

[8] Laudon, Knneth C, Sistem Informasi Managemen Edisi Kedelapan, Andi, Yogyakarta, 2008
[9] Madcoms. Aplikasi Program PHP dan MySql, Penerbit Andi, Yogyakarta, 2004.

[10] Tarigan, Daud Edison. 2012. Membangun SMS Gateway Berbasis Web dengan Codeigniter. Yogyakarta. Lokomedia

[11] Fadilah Wati, Siska, Sistem Informasi Penjualan Dan Pemesanan Layanan Berbasis Web Dan Sms Gateway Di Pet Shop "Petzone", Skripsi S-1 Universitas Diponegoro, Semarang, 2013.

[12] Daqiqil, Ibnu. Frame Work Codeigniter Sebuah Panduan Belajar dan Praktis https://www.academia.edu/3647990/Framework Codeigniter.pdf, 5 Mei 2014. 